\title{
ПУБЯІЧНЕ ПРАВО
}

УДК 342.58:338.43 DOI: https://doi.org/10.31617/zt.knute.2020(108)07

МУШЕНОК Віктор д. ю. н., доцент, професор кафедри загальноправових дисциплін Київського національного торговельно-економічного університету

E-mail:mushenook@gmail.com вул. Кіото, 19, м. Київ, 02156, Україна

\section{ДЕРЖАВНА ПІДТРИМКА РОЗВИТКУ СІЛЬСЬКОГОСПОДАРСЬКОЇ ДОРАДЧОЇ ДІЯЛЬНОСТІ}

Досліджено теоретико-правові засади бюджетної підтримки вітчизняної сільськогосподарської дорадчої діяльності. Проаналізовано позицію Мінекономіки щодо перспектив ненадання такої підтримки в 2020 рочі. В межах проблематики дослідження на основі статистичних матеріалів, чинних локальних нормативноправових актів і передового закордонного досвіду зроблено спробу обтрунтувати хибність позииії Мінекономіки та запропоновано спосіб удосконалення механізму правового забезпечення стабільної бюджетної підтримки державою суб'єктів сільськогосподарської дорадчої діяльності.

Ключові слова: аграрна політика, бюджетне регулювання, державна підтримка, закордонний досвід, Мінекономіки, правове забезпечення, сільськогосподарська дорадча діяльність.

Мушенок В. Государственная поддержкка развития сельскохозяйственной консультативной деятельности. Исследованы теоретико-правовые основы бюджетной поддержки отечественной сельскохозяйственной консультативной деятельности. Проанализирована позииия Минэкономики относительно перспектив непредоставления такой поддержки в 2020 году. В рамках проблематики исследования на основе статистических материалов, действующих локальных нормативноправовых актов, передового зарубежного опыта сделана попытка обосновать ошибочность позиции Минэкономики и предложен способ усовершенствования механизма правового обеспечения стабильной бюджетной поддержки государством субъектов сельскохозяйственной консультативной деятельности.

Ключевые слова: аграрная политика, бюджетное регулирование, государственная поддержка, зарубежный опыт, Минэкономики, правовое обеспечение, сельскохозяйственная консультативная деятельность.

Постановка проблеми. Поступ нашої держави до європейського соціально-економічного простору нерозривно пов'язаний із удосконаленням фінансово-правового регулювання відносин в аграрному секторі

(C) Мушенок В., 2020 
економіки України (надалі - аграрний сектор). Подолання кризового стану, в якому перебуває вся економіка України, неможливе без нормативно-правового забезпечення державою інтересів виробників сільськогосподарської продукції. Удосконалення механізмів бюджетної підтримки сільськогосподарської дорадчої діяльності наразі залишається для України важливою складовою проблеми правового регулювання відносин в аграрному секторі та є серйозним чинником забезпечення подальшого існування й розвитку держави в сучасних світових соціально-політичних умовах.

У ряді закордонних країн із значною часткою аграрного виробництва в структурі ВВП і національного доходу потреба в отриманні різнопланової, орієнтованої на вузьку професійну спеціалізацію інформації виробниками сільськогосподарської продукції, їхнє навчання, підвищення фахового рівня тощо є актуальним, доцільним, ефективним і неодмінним видом консультативної діяльності. Адже стабільний розвиток аграрного сектору економіки кожної країни значною мірою залежить від нормативно-правового забезпечення динамічного освоєння новітніх технологій виробництва продукції та використання різноманітних можливостей сучасної ринкової кон'юнктури.

Аналіз основних досліджень і публікацій. Вивчення сучасними науковцями-правниками проблем правового регулювання відносин в аграрному секторі, аналіз законодавчих повноважень і можливостей консультативних сільськогосподарських організацій, а також стан їхньої підтримки з боку держави в цілому є недостатнім. У суспільнополітичних та економічних умовах наразі актуальними для детального наукового дослідження стали питання сучасного стану правового забезпечення бюджетної підтримки сільськогосподарських дорадчих організацій. Певних здобутків у дослідженні проблематики фінансовоправового регулювання відносин сільськогосподарського дорадництва досягли лише окремі представники вітчизняної та закордонної правової й економічної науки, як-от: М. Безкровний [1], Т. Коваленко [2], Р. Корінець [3], Н. Похиленко [3-4], Л. Тараненко [5], Б. Свенсон i Р. Раджалатті [6], Дж. Гайо [7] тощо.

Здебільшого 3 огляду на доктринальні напрацювання учених щодо перспектив розвитку сільськогосподарської дорадчої діяльності можна констатувати, що поза їхньою увагою залишилися важливі питання законодавчого забезпечення суб'єктів такої діяльності стабільною бюджетною підтримкою в системі реалізації заходів державної підтримки аграрного сектору вітчизняної економіки.

Метою статті $\epsilon$ аналіз стану правового регулювання відносин бюджетного забезпечення вітчизняних і закордонних суб'єктів сільськогосподарської дорадчої діяльності та на підставі його результатів формування пропозицій щодо законодавчого гарантування можливостей отримання реальної державної підтримки суб'єктами цієї сфери суспільно-економічних відносин в Україні. 
Матеріали та методи. Інформаційною базою дослідження стали нормативно-правові акти України, зокрема закони України «Про сільськогосподарську дорадчу діяльність», «Про Державний бюджет України на 2020 рік», праці науковців у галузі права та економіки. Методологічною основою дослідження є загальнонаукові та спеціально-юридичні методи пізнання, використання яких забезпечило високий ступінь достовірності отриманих результатів щодо визначення взаємного впливу суспільно-економічних чинників, що обумовлює ефективність розвитку аграрного сектору в Україні.

Результати дослідження. Державна підтримка суб'єктів аграрного сектору є одним із важливих напрямів державної аграрної політики та полягає в закріпленні в законодавстві системних методів позитивного впливу на фінансово-господарський стан таких суб'єктів, зокрема шляхом розбудови дієвої системи сільськогосподарського дорадництва, що є одним iз важливих завдань сучасного державотворення та невід'ємною складовою євроінтеграційного процесу.

Аргументом на користь авторської позиції є й положення Угоди про асоціацію між Україною та Свропейським Союзом щодо визначення обов'язків сторін сприяти «просуванню системи дорадництва до сільськогосподарських виробників» [8]. Окрім того, Угода містить інформацію про те, що «основними стримуючими факторами розвитку сільськогосподарської дорадчої діяльності в Україні є незабезпечення становлення та розвитку інституційної бази дорадництва» [8].

Організаційно-правову основу формування національної системи сільськогосподарського дорадництва визначено Законом України «Про сільськогосподарську дорадчу діяльність» від 17 червня 2004 року № 1807-IV, згідно з яким дорадництво - це один із методів реалізації державної політики в сфері аграрного виробництва та є «сукупністю дій і заходів, спрямованих на задоволення потреб особистих селянських та фермерських господарств, різних типів сільськогосподарських підприємств, сільського населення у підвищенні рівня знань і вдосконалення практичних навичок прибуткового господарювання» [9].

Дорадчу діяльність (дорадництво) здійснюють сільськогосподарські дорадчі служби, у складі яких працюють сільськогосподарські дорадники та/або експерти-дорадники, що пройшли реєстрацію відповідно до законодавства та внесені до Реєстру дорадників. Головною метою діяльності суб'єктів дорадництва $€$ надання консультаційних послуг сільськогосподарським виробникам з питань економіки, технологій, управління, маркетингу, обліку, податків, права, екології, зайнятості сільського населення, впровадження у виробництво сучасних технологій, сприяння розвитку сільського зеленого туризму тощо.

За офіційними даними, в Україні на кінець 2019 р. зареєстровано 86 сільськогосподарських дорадчих служб, що об'єднані у Всеукраїнську громадську організацію «Національна асоціація сільськогосподарських дорадчих служб України». Метою діяльності асоціації 
є сприяння покращенню добробуту сільського населення та розвитку сільської місцевості шляхом підвищення рівня знань і вдосконалення практичних навичок сільського населення та сільськогосподарських товаровиробників, задоволення й захист соціальних, економічних, фахових та інших спільних інтересів членів асоціації [10].

Фінансову основу дорадчої діяльності визначено в ст. 8. Закону України «Про сільськогосподарську дорадчу діяльність», зокрема прописано, що у Державному бюджеті України (надалі - ДБ України) на відповідний рік передбачено кошти для фінансування державної цільової програми сільськогосподарської дорадчої діяльності, а порядок використання цих коштів визначає Кабінет Міністрів України (надалі КМ України) [9].

Досліджуючи законодавче закріплення механізму бюджетноправового регулювання відносин держави із сільськогосподарськими дорадчими службами, варто зауважити на цьогорічних перспективах державної фінансової підтримки дорадництва. Відповідно до Закону України «Про Державний бюджет України на 2020 рік» від 14.11.2019 № 294-IX (Додаток 3) за кодом програмної класифікації 1201150 «Фінансова підтримка сільгосптоваровиробників» у 2020 р. як видатки на розвиток в загальний фонд ДБ України закладено 4 млрд грн [11].

Міністерство розвитку економіки, торгівлі та сільського господарства (надалі - Мінекономіки) («центральний орган виконавчої влади, діяльність якого спрямовує та координує Кабінет Міністрів України, та $є$ головним органом у системі центральних органів виконавчої влади, що забезпечує формування та реалізує державну аграрну політику, державну політику у сфері сільського господарства» [12]) орієнтовно визначило базові напрями державної підтримки аграрної галузі на 2020 р., зокрема «садівництво, тваринництво, здешевлення сільськогосподарської техніки та обладнання, фермерство, дорадництво, здешевлення кредитів», та передбачає за зазначеними напрямами надати часткову компенсацію вартості сільськогосподарської техніки та обладнання 1 млрд грн; виділити кошти на розвиток тваринництва - 1 млрд грн; здешевлення кредитів - 1,2 млрд грн; розвиток садівництва та фермерства - по 400 млн грн [13].

Така інформація дає підстави стверджувати про порушення ст. 8 Закону України «Про сільськогосподарську дорадчу діяльність», де зазначено, що «у державних цільових програмах, спрямованих на розвиток сільського господарства та сільської місцевості, прогнозовано фінансування дорадчої діяльності в розмірі не менше ніж 5 відсотків коштів, передбачених для цих програм» [9], тобто визначений базовий напрям державної підтримки аграрного сектору на 2020 рік, який має бути профінансований на суму не менше ніж 200 млн грн, фактично не отримає бюджетної підтримки.

За результатами аналізу зазначеної вище позиції Мінекономіки можна зробити висновок, що держава не має за мету в 2020 році (як й у 2011 та 2013 рр. [14]) забезпечувати державну підтримку суб'єктів 
сільськогосподарської дорадчої діяльності. Тож для обгрунтування хибності позиції Мінекономіки у цьому питанні та на захист забезпечення державної бюджетної підтримки сільськогосподарської дорадчої діяльності можна навести (як докази), відповідно, статистичний матеріал, факти невиконання попередніх чинних нормативних розпоряджень, а також приклади передового закордонного досвіду.

Наявні на офіційному сайті Мінекономіки [15] звернення профільних сільськогосподарських асоціацій щодо держпідтримки можна згрупувати за такими напрямами: компенсація невиплачених коштів за попередній період; тваринництво, у тому числі компенсація вартості тваринницьких комплексів; відшкодування за придбання племінних тварин; здешевлення сільськогосподарської техніки та обладнання; садівництво; дорадництво; здешевлення кредитів; підтримка пасічників, у тому числі виплати дотації на купівлю бджолосімей; підтримка фермерства, у тому числі сімейних фермерських господарств; підтримка сільськогосподарських виробничих та обслуговуючих кооперативів; кредитування малих виробників; залучення коштів під купівлю земель сільськогосподарського призначення тощо.

Отже, очевидно, що у сільськогосподарських виробників, особливо кооперативів, фермерських та особистих селянських господарств існує нагальна необхідність в отриманні фахових різнопланових сільськогосподарських дорадчих послуг.

$>$ Важливим питанням державного забезпечення розвитку системи сільськогосподарського дорадництва $є$ виділення бюджетного фінансування на забезпечення виконання розпоряджень КМ України від 31.10.2011 № 1098-р «Про схвалення Концепції формування державної системи сільськогосподарського дорадництва» [16] та від 23.05.2012 № 303-p «Про затвердження плану заходів щодо реалізації Концепції формування державної системи сільськогосподарського дорадництва на період до 2015 року» [17]. Зокрема здійснення двох важливих організаційних заходів модернізації сільськогосподарської дорадчої діяльності: створення Національного центру дорадництва та регіональних сільськогосподарських дорадчих служб; забезпечення використання існуючого науково-освітнього потенціалу в системі аграрної освіти та Національної академії аграрних наук.

Виконання зазначених вище розпоряджень КМ України сприятиме вдосконаленню у системі існуючої сільськогосподарської дорадчої діяльності наразі відсутніх, проте дуже необхідних двох напрямів: дослідження можливостей впровадження європейського досвіду інформаційно-консультаційного забезпечення сільськогосподарських виробників; формування дорадчих служб на кооперативних засадах та засадах державно-приватного партнерства із залученням підприємницьких, професійних і громадських організацій.

$>$ Аналіз наявного закордонного досвіду державної фінансової підтримки сільськогосподарських дорадчих служб із використанням опублікованих матеріалів Національного інституту стратегічних досліджень 
показує, що сільськогосподарська дорадча служба Канади є неодмінною складовою міністерства сільського господарства і продовольства Канади (входить до департаменту регіональних дорадчих послуг) [15]. Дорадчі служби США фінансуються 3 державних і регіональних джерел, як-то: міністерство сільського господарства США - 25 \%; Уряд штату $40 \%$; Уряд округу $-35 \%$.

Структурованою та ефективною є система сільськогосподарського дорадництва і в Республічі Польщза, де дорадчі служби створені та функціонують за безпосередньої підтримки держави. Внаслідок здійснення державою фінансування суб'єктів дорадчої діяльності сільськогосподарські виробники мають можливість отримати безкоштовну консультативну інформацію з широкого кола питань: виробництва тваринницької та вирощування рослинницької продукції, управління земельними ресурсами, маркетингу продукції, захисту довкілля тощо.

У Великій Британії дорадча служба сформована винятково державою. Послуги по різних видах сільськогосподарським виробникам надавалися безкоштовно. Сама служба цілком утримувалася завдяки державному бюджету. 31997 р. у Великій Британії сільськогосподарська дорадча служба, яку реформовано шляхом приватизації, існує та розвивається внаслідок комерціалізації власної дорадчо-консультативної діяльності. Правова парадигма фінансових взаємовідносин дорадчої служби з державою змінилася таким чином, що держава стала одним із замовників послуг дорадчої служби. Проте державна політика щодо бюджетної підтримки суб'єктів дорадчої діяльності у Великій Британії $\epsilon$ незмінною.

Узагальнюючи закордонний досвід державної фінансової підтримки сільськогосподарського дорадництва, варто зазначити, що така підтримка $\epsilon, з$ одного боку, складовою національних вимог ведення сільськогосподарської діяльності; 3 іншого - способом ефективного впливу держави на підвищення рівня доходів і конкурентоспроможності сільськогосподарських виробників та підтримання сталого розвитку сільських територій тощо.

Механізм бюджетної підтримки сільськогосподарської дорадчої діяльності має бути удосконалений із урахуванням двох пропозицій. По-перше, відповідно до абзацу 1 ст. 8 Закону України «Про сільськогосподарську дорадчу діяльність» [9] у Додатку 3 Закону України «Про Державний бюджет України на 2020 рік» за кодом програмної класифікації 1201150 «Фінансова підтримка сільгосптоваровиробників» окремим рядком передбачити кошти для фінансування державної цільової програми сільськогосподарської дорадчої діяльності. По-друге, зі ст. 8. Закону України «Про сільськогосподарську дорадчу діяльність» вилучити абзац 2 такого змісту: «Порядок використання коштів державної цільової програми сільськогосподарської дорадчої діяльності визначається Кабінетом Міністрів України» [9]. 
Пропозиції щодо зміни правового механізму надання бюджетної підтримки дорадчим службам зміцнять їхню фінансову основу, оскільки позбавлять Мінекономіки як головного органу в системі центральних органів виконавчої влади, що забезпечує формування та реалізує державну аграрну політику, можливості необгрунтованої відмови у виділенні бюджетних коштів на розвиток сільськогосподарської дорадчої діяльності в нашій державі.

Висновки. Невиділення коштів 3 ДБ України для фінансування сільськогосподарської дорадчої діяльності у 2020 р., як і в деяких попередніх роках, свідчить не лише про намагання Мінекономіки проігнорувати приписи ст. 8. Закону України «Про сільськогосподарську дорадчу діяльність», а й про неусвідомлення значення дорадництва у процесі реалізації основних засад державної аграрної політики. Адже низький рівень розвитку системи дорадництва послаблює конкурентоспроможність аграрного сектору, оскільки продуктивність та ефективність виробництва його суб'єктів зменшується у кілька разів проти країн із розвиненою інфраструктурою дорадництва. Така позиція Мінекономіки також повністю суперечить досвіду розвинених європейських країн, де державна підтримка сільськогосподарської дорадчої діяльності є одним із ключових інструментів: сприяння розвитку сільських територій; стимулювання економічного зростання суб'єктів аграрного сектору; подолання бідності та підвищення рівня добробуту сільського населення тощо.

Запропоновані зміни правового механізму надання з ДБ України коштів на державну підтримку сприятимуть стабілізації фінансової бази сільськогосподарської дорадчої діяльності. Багаторічні авторські дослідження фінансово-правового регулювання відносин в аграрному секторі дають підстави стверджувати, що витрачені державою кошти на фінансування дорадчої діяльності зможуть компенсувати збільшення дохідності суб'єктів сільськогосподарського виробництва та відповідно повернуться до бюджету через зростання податкових надходжень.

Перспективою подальших наукових досліджень $є$ вивчення аргументів на користь реформування системи державної підтримки дорадчих служб у частині створення законодавчих засад забезпечення механізму авансового фінансування з ДБ України на противагу існуючому - за фактом виконання робіт, оскільки незначний обсяг власних обігових коштів не забезпечує можливість оплатити витрати на підготовку та здійснення дорадчих заходів.

\section{СПИСОК ВИКОРИСТАНИХ ДЖЕРЕ}

1. Безкровний М. Ф. Державне регулювання сільськогосподарської дорадчої діяльності. Ефективна економіка. 2017. № 6. URL: http://www.economy.nayka.com.ua/ ?op $=1 \& \mathrm{z}=5675$.

2. Коваленко Т. О. До питання сільськогосподарської дорадчої діяльності. Інформаиійноаналітична газета «Агробізнес сьогодні». 2014. URL: http://agro-business.com.ua/agro/ u-pravovomu-poli/item/1852-do-pytannia-silskohospodarskoi-doradchoi-diialnosti.html. 
3. Корінець Р. Я., Похиленко Н. М. Фінансування системи сільськогосподарського дорадництва. Глобальні та національні проблеми економіки. 2018. № 23. С. 109-115.

4. Похиленко Н. М. Ретроспектива парадигм сільськогосподарського дорадництва: варіанти для України. Економіка АПК. 2018. № 7. С. 113-121.

5. Тараненко Л. С. Поняття та сутність сільськогосподарської дорадчої діяльності. Науковий вісник Ужггородського національного університету. 2014. Вип. 24. Т. 3. С. 20-24. Серія Право.

6. Swanson Burton E., Rajalahti Riikka. Strengthening Agricultural Extension and Advisory Systems: Procedures for Assessing, Transforming, and Evaluating Extension Systems. 2010. P. 7-11. URL: http://siteresources.worldbank.org/INTARD/Resources/ Stren_combined_web.pdf.

7. Jose Rene C. Gayo. A new paradigm for agricultural extension. 2012. URL: http://business.inquirer.net/72689/a-new-paradigm-for-agricultural-extension.

8. Угода про асоціацію між Україною, з однієї сторони, та Європейським Союзом, Європейським співтовариством 3 атомної енергії і їхніми державами-членами, з іншої сторони від 21 березня 2014 р. № 984 011. URL: https://zakon.rada.gov.ua/ laws/show/984_011" \1 "n2820.

9. Про сільськогосподарську дорадчу діяльність: Закон України від 17 червня 2004 р. № 1807-IV. Відомості Верховної Ради України. 2004. № 38. С. 470.

10. Національна асоціація сільськогосподарських дорадчих служб України. Офіційний сайт. URL: https://www.dorada.org.ua/pro-asotsiatsiyu/pro-nasdsu.html.

11. Про Державний бюджет України на 2020 рік: Закон України від 14 листопада 2019 року № 294-IX. URL: https://zakon.rada.gov.ua/laws/show/294-20?find=1\&text.

12. Положення про Міністерство розвитку економіки, торгівлі та сільського господарства України: Затв. Постанова Кабінету Міністрів України від 20 серпня 2014 р. № 459 (в редакції постанови Кабінету Міністрів України від 11 вересня 2019 р. № 838). URL: https://zakon.rada.gov.ua/laws/show/838-2019-\%D0\%BF.

13. У Мінекономіки назвали базові напрями держпідтримки АПК на 2020 рік. Економічна правда від 21 січня 2020. URL: https://www.epravda.com.ua/news/ 2020/01/21/656085.

14. Щодо державної підтримки розвитку сільськогосподарського дорадництва в Україні. Аналітична записка. Національний інститут стратегічних досліджень. URL: http://old2.niss.gov.ua/articles/1521.

15. Офіційний сайт Міністерства розвитку економіки, торгівлі та сільського господарства. URL: http://www.me.gov.ua.

16. Про схвалення Концепції формування державної системи сільськогосподарського дорадництва: Розпорядження Кабінету Міністрів України від 31 жовтня 2011 р. № 1098-p. URL: https://zakon.rada.gov.ua/laws/show/1098-2011-\%D1\%80.

17. Про затвердження плану заходів щодо реалізації Концепції формування державної системи сільськогосподарського дорадництва на період до 2015 року: Розпорядження Кабінету Міністрів України від 23 травня 2012 р. № 303-p. URL: https://zakon.rada.gov.ua/laws/show/1098-2011-\%F0.

Стаття надійшла до редакиіï 27.01.2020.

Mushenok V. State support for the development of agricultural advisory activity.

Background. Overcoming the crisis of the economy of Ukraine is impossible without the legal provision of state interests of agricultural producers. Improving the legal mechanisms of budget support for agricultural advisory activity remains an important part of the problem of legal regulation of relations in the agricultural sector.

Analysis of resent researches and publications. It is established that only some representatives of domestic economic and legal science, such as M. Bloodless, T. Kovalenko, R. Korinets, N. Pokhilenko, L. Taranenko, B. Swanson and R. Rajalahti, J. Gayo and others have some achievements in studying the problems of legal regulation of agrarian advisory relations. 
The aim of the article is to characterize the state of legal regulation of budget support for agricultural advisory as an important socio-economic activity for the development of our country and justify the feasibility of further budget support by the state for such activity.

Material and methods. The information base of the research was the current normative legal acts of Ukraine, the works of scientists. The methodological basis of the study was the general scientific and special legal methods of cognition, the use of which provided a high degree of reliability of the results.

Results. The Law of Ukraine "On Agricultural Advisory Activities» defines: advisory as one of the methods of implementation of state policy in the field of agriculture. This law also guarantees the allocation of budget funds for the financing of the state targeted program of agricultural advisory activities. An analysis of the official position of the Ministry of Economy leads to the conclusion that the state does not intend in 2020 to provide state support to entities of advisory activity. The author substantiates the flawed position of the Ministry of Economy and the defense of the position on the provision of state budget support for agricultural advisory activity, as evidence, respectively, statistical material, facts of failure to comply with regulations, and examples of foreign experience.

Conclusion. State support for advisory activities is a way of effectively influencing the state to raise the incomes of agricultural producers and maintain sustainable development of rural areas. The low level of development of the advisory system in Ukraine impairs the competitiveness of the agricultural sector entities. The domestic agricultural advisory system is to be financed from the state budget in 2020. The proof of the effectiveness of such state support is that government spending on advisory activities can be offset by an increase in agricultural yield and, accordingly, will be repaid due to an increase in the level of tax revenue from agrarian entities.

Keywords: agrarian policy, budget regulation, state support, foreign experience, Ministry of Economy, legal support, agricultural advisory activities.

\section{REFERENCES}

1. Bezkrovnyj, M. F. (2017). Derzhavne reguljuvannja sil's'kogospodars'koi' doradchoi' dijal'nosti [The state regulation of agricultural advisory activity]. Efektyvna ekonomika An efficient economy. 6. Retrieved from http://www.economy.nayka.com.ua/ ?op $=1 \& \mathrm{z}=5675$ [in Ukrainian].

2. Kovalenko, T. O. (2014). Do pytannja sil's'kogospodars'koi' doradchoi' dijal'nosti [On the issue of agricultural advisory activities]. Informacijno-analitychna gazeta «Agrobiznes s'ogodni» - Information-analytical newspaper «Agrobusiness today». Retrieved from http://agro-business.com.ua/agro/u-pravovomu-poli/item/1852-do-pytanniasilskohospodarskoi-doradchoi-diialnosti.html [in Ukrainian].

3. Korinec', R. Ja., \& Pohylenko, N. M. (2018). Finansuvannja systemy sil's'kogospodars'kogo doradnyctva [Financing the agricultural advisory system]. Global'ni ta nacional'ni problemy ekonomiky - Global and national problems of economy, 23, 109-115 [in Ukrainian].

4. Pohylenko, N. M. (2018). Retrospektyva paradygm sil's'kogospodars'kogo doradnyctva: varianty dlja Ukrai'ny [A retrospective of agricultural advisory paradigms: options for Ukraine]. Ekonomika APK - APK economy, 7, 113-121 [in Ukrainian].

5. Taranenko, L. S. (2014). Ponjattja ta sutnist' sil's'kogospodars'koi' doradchoi' dijal'nosti [The concept and essence of agricultural advisory activities]. Naukovyj visnyk Uzhgorods'kogo nacional'nogo universytetu - The scientific bulletin of Uzhgorod National University, 24, (Vol. 3), (pp. 20-24). Ser. Law [in Ukrainian].

6. Swanson, Burton. E., \& Rajalahti, Riikka. (2010). Strengthening Agricultural Extension and Advisory Systems: Procedures for Assessing, Transforming, and Evaluating Extension Systems. (pp. 7-11). Retrieved from http://siteresources.worldbank.org/ INTARD/Resources/Stren_combined_web.pdf [in English]. 
7. Gayo, Jose Rene C. (2012). A new paradigm for agricultural extension. Retrieved from http://business.inquirer.net/72689/a-new-paradigm-for-agricultural-extension [in English].

8. Ugoda pro asociaciju mizh Ukrai'noju, z odnijei' storony, ta Jevropejs'kym Sojuzom, Jevropejs'kym spivtovarystvom $\mathrm{z}$ atomnoi' energii' i i'hnimy derzhavamy-chlenamy, z inshoi' storony vid 21 bereznja 2014 roku № 984_011 [Association agreement between Ukraine, on the one hand, and the European Union, the European Atomic Energy Community and their member states, on the other hand of 21 March 2014 № 984_011]. Retrieved from https://zakon.rada.gov.ua/laws/show/984_011"ll"n2820 [in Ukrainian].

9. Pro sil's'kogospodars'ku doradchu dijal'nist': Zakon Ukrai'ny vid 17 chervnja 2004 roku № 1807-IV [On agricultural advisory activities: the Law of Ukraine of June 17, 2004 № 1807-IV] (2004). Vidomosti Verhovnoi' Rady Ukrai'ny - Information of the Verkhovna Rada of Ukraine, 38 [in Ukrainian].

10. Nacional'na asociacija sil's'kogospodars'kyh doradchyh sluzhb Ukrai'ny [National association of agricultural advisory services of Ukraine]. Oficijnyj sajt [Official site]. Retrieved from https:/www.dorada.org.ua/pro-asotsiatsiyu/pro-nasdsu.html [in Ukrainian].

11. Pro Derzhavnyj bjudzhet Ukrai'ny na 2020 rik: Zakon Ukrai'ny vid 14 lystopada 2019 roku № 294-IX [On the State budget of Ukraine for 2020: the Law of Ukraine of November 14, 2019 № 294-IX]. Retrieved from https://zakon.rada.gov.ua/laws/ show/294-20?find=1\&text [in Ukrainian].

12. Polozhennja pro Ministerstvo rozvytku ekonomiky, torgivli ta sil's'kogo gospodarstva Ukrai'ny: Zatv. Postanova Kabinetu Ministriv Ukrai'ny vid 20 serpnja 2014 r. № 459 (v redakcii' postanovy Kabinetu Ministriv Ukrai'ny vid 11 veresnja 2019 r. № 838) [Regulation on the Ministry of economic development, trade and agriculture of Ukraine: Approved. The Resolution of the Cabinet of Ministers of Ukraine of August 20, 2014 № 459 (as amended by the resolution of the Cabinet of Ministers of Ukraine of September 11, 2019 № 838)]. Retrieved from https://zakon.rada.gov.ua/laws/show/ 838-2019-\%D0\%BF [in Ukrainian].

13. U Minekonomiky nazvaly bazovi naprjamy derzhpidtrymky APK na 2020 rik [The Ministry of Economy named the basic directions of state support of agroindustrial complex for 2020] (2020). Ekonomichna pravda - Economic truth. Retrieved from https://www.epravda.com.ua/news/2020/01/21/656085 [in Ukrainian].

14. Shhodo derzhavnoi' pidtrymky rozvytku sil's'kogospodars'kogo doradnyctva v Ukrai'ni. Analitychna zapyska [Regarding state support for agricultural advisory development in Ukraine. Analytical note]. Nacional'nyj instytut strategichnyh doslidzhen' [National Institute for Strategic Studies]. Retrieved from http://old2.niss.gov.ua/articles/1521 [in Ukrainian].

15. Oficijnyj sajt Ministerstva rozvytku ekonomiky, torgivli ta sil's'kogo gospodarstva [The official site of the Ministry of Economic Development, Trade and Agriculture]. Retrieved from http://www.me.gov.ua [in Ukrainian].

16. Pro shvalennja Koncepcii' formuvannja derzhavnoi' systemy sil's'kogospodars'kogo doradnyctva: Rozporjadzhennja Kabinetu Ministriv Ukrai'ny vid 31 zhovtnja 2011 r. № 1098-r. [On approval of the Concept of formation of the state system of agricultural advisory: The Order of the Cabinet of Ministers of Ukraine of October 31, 2011 № 1098-r.]. Retrieved from https://zakon.rada.gov.ua/laws/show/1098-2011-\%D1\%80 [in Ukrainian].

17. Pro zatverdzhennja planu zahodiv shhodo realizacii' Koncepcii' formuvannja derzhavnoi' systemy sil's'kogospodars'kogo doradnyctva na period do 2015 roku: Rozporjadzhennja Kabinetu Ministriv Ukrai'ny vid 23 travnja 2012 r. № 303-r. [On approval of the plan of measures for the Implementation of the Concept of formation of the state system of agricultural advisory for the period up to 2015: the Order of the Cabinet of Ministers of Ukraine of May 23, 2012 № 303-p.]. Retrieved from https://zakon.rada.gov.ua/laws/show/1098-2011-\%F0 [in Ukrainian]. 